\title{
KONSEPSI RELASI SOSIAL DALAM PERSPEKTIF AL-QUR'AN
}

\author{
Aas Siti Sholichah \\ Dosen Fakultas Tarbiyah I-PTIQ \\ shalichah@gmail.com
}

\begin{abstract}
Appreciation of the Qur'an in social relations is implied in the QS. Al-Hujurat / 49: 13. In this verse Allah SWT created tribal men, women, nationalities, different languages, even each human being has differences both physically and personally. The purpose of human creation is to get to know one another, which can form a fabric of cooperation and synergy. Mutual respect and respect in different beliefs, nations, tribes, and countries are also different languages, so as to create peace and tranquility in social life.
\end{abstract}

Keywords: Human, Social Relations, Al-Qur'an

\begin{abstract}
ABSTRAK
Apresiasi Al-Qur'an dalam relasi sosial diisyaratkan dalam QS. Al- Hujurat/49:13. Dalam ayat tersebut Allah SWT menciptakan manusia laki-laki dan perempuan bersuku-suku, berbangsa-bangsa, berbeda bahasa, bahkan setiap manusia memiliki perbedaan baik secara fisik dan kepribadian. Tujuan diciptakannya manusia adalah untuk saling mengenal satu sama lain, yang dapat membentuk jalinan kerjasama dan sinergitas. Saling menghargai dan menghormati dalam keyakinan yang berbeda, bangsa, suku, dan negara juga bahasa yang berbeda, sehingga dapat menciptaan ketenangan dan ketenteraman dalam kehidupan sosial.
\end{abstract}

Kata Kunci: Manusia, Relasi Sosial, Al-Qur'an 


\section{A. Pendahuluan}

Manusia sebagai makhluk sosial keberadaannya tidak dapat terlepas dari manusia lainnya. Kebutuhan akan hidup bersama-sama menjadikan manusia saling mengenal, mengamati, menghargai dan menerima kelebihan dan kekurangan manusia lain. Berbagai cara dilakukan untuk dapat bersosialisasi dengan pihak lain, mulai dari membangun komunikasi secara lisan maupun komunikasi secara tertulis. Terlebih dengan kemajuan teknologi dan informasi memberikan banyak peluang setiap manusia untuk melakukan komunikasi dan kontak sosial dengan manusia lain. Tidak hanya sebatas teman antar wilayah dan daerah, komunikasi dapat dibangun tanpa mengenal jarak, ruang dan waktu. Kemajuan teknologi telah melahirkan berbagai bentuk komunikasi mulai dari surat menyurat, melakukan kontak telepon, berkirim info dengan email bahkan yang lebih maju saat ini antar manusia disatu negara dengan manusia di negara lain dapat melakukan komunikasi secara langsung. Kemajuan informasi yang ditopang oleh kemajuan teknologi telah memberikan kemudahan setiap manusia untuk melakukan relasi sosial.

Relasi sosial merupakan hubungan yang dibangun oleh seseorang atau sekelompok orang untuk melakukan komunikasi yang dapat menghasilkan komunikasi yang baik yang dapat berhubungan dengan wilayah pekerjaan, persaudaraan, mediasi dan proses belajar mengajar.

Kemajuan ilmu pengetahuan dan teknologi telah banyak memberikan manfaat untuk manusia dalam menjalin relasi sosial. Berbagai lingkup dapat dengan mudah dilakukan, mulai dari hubungan kekeluargaan, hubungan pekerjaan, hubungan antar negara dan lainnya. Namun kemajuan ilmu pengetahuan dan teknologi juga telah memberikan dampak negatif terhadap pola relasi sosial. Berdasarkan data yang dipaparkan oleh Kementerian Komunikasi dan Informatika tahun 2016 sebanyak 800 ribu situs di Indonesia yang terindikasi sebagai penyebar berita palsu dan ujaran kebencian. ${ }^{1}$

Selain itu persentasi angka berita hoax tertinggi adalah kabar yang bermuatan politik. Berdasarkan data yang diungkap Masyarakat Telematika (Mastel) sebagian besar porsi penyebaran berita hoax di Indonesia jumlahnya mencapai $91,80 \%$. Sedangkan di posisi kedua, topik seputar Sara juga cukup mendominasi yakni $88,60 \% .^{2}$

Tingginya penyebaran berita bohong melalui media sosial menjelaskan bahwa telah terjadi masalah sosial yang dapat menyebabkan keresahan dan ketidaknyamanan antar sesama terlebih menjelang pemilihan umum usat dan daerah, potensi penyebaran berita bohong sanagt tinggi, hal ini dapat dilihat di

1 https://www.cnnindonesia.com/teknologi/20161229170130-185-182956/ada-800ribu-situs-penyebar-hoax-di-indonesia/ diakses 27 Oktober 2017.

2 https://techno.okezone.com/read/2017/02/13/207/1616892/lebih-dari-90-berita-hoaxdi-indonesia-bermuatan-politik diakses 27 Oktober 2017. 
media sosial seperti facebook, whatsup, Instagram, twitter. Perilaku ini dilakukan untuk memuaskan kepentingan pribadi dan golongan.

Dalam Al-Qur'an, relasi sosial yang dilakukan oleh setiap manusia sudah diatur dengan lengkap dan rinci, berbagai ayat menjelaskan tentang pentingnya menghargai dan menciptakan ketenangan dan kedamaian serta aturan mengenai larangan melakukan perbuatan dan perkataan baik yang menyakiti maupun memancing permusuhan.

Makalah ini akan memaparkan konsep Al-Qur'an mengenai relasi sosial dalam kehidupan sehari-hari baik yang berkaitan dengan lingkup sosial maupun lingkup politik.

\section{B. Metode Penelitian}

Dalam penelitian ini penulis menggunakan metode penelitian kualitatif, Adapun pendekatan penelitian yang digunakan bersifat library research (penelitian kepustakaan) atau disebut juga content analysis (analisis isi). Adapun teknis pengumpulan data yang dilakukan yaitu mencatat data-data yang diambil dari berbagai sumber dari bahan-bahan tertulis kemudian mengidentifikasi bukti-bukti kontekstual yaitu dengan mencari hubungan antara data dengan realitas yang penulis teliti. Pengolahan data dalam penelitian ini bersifat kualitatif maka dilakukan dengan analisis kritis, komparasi, serta interpretasi atas berbagai hasil penelusuran dari sumber-sumber primer dan sekunder.

\section{Relasi Sosial dalam Perspektif Al-Qur'an \\ 1. Hakikat Manusia}

Definisi manusia menurut kamus Bahasa Indonesia adalah "Makhluk yang berakal, berbudi (mampu menguasai makhluk lain)". ${ }^{3}$ Sedangkan dalan bahasa arab, kata manusia disepadankan dengan kata nâs, basyar, insan, mar'u dan ins. ${ }^{4}$

Menurut pengertian di atas, manusia merupakan makhluk Allah SWT yang diberikan potensi akal fikiran dan budi, moral dan nalar untuk dapat menguasai makhluk lain demi tercapainya kehidupan yang makmur dan maslahat.

Dalam pandangan ilmu pengetahuan, manusia memiliki beberapa pendapat dan argumen yang disesuaikan dengan metodologi yang dikembangkan. Penganut teori behaviorisme berpendapat bahwa manusia sebagai homo mehanibcus (manusia mesin). Dasar pemikiran ini bahwa segala tingkah laku manusia terbentuk sebagai proses belajar manusia terhadap lingkungan.

\footnotetext{
${ }^{3}$ Usman A. Hakim, Kamus Bahasa Indonesia (Jakarta: Balai Pustaka, 2001), 212.

${ }^{4}$ Abdullah bin Nuh, Kamus Indonesia Arab (Jakarta: Mutiara, 2008), 135.
} 
Sedangkan penganut teori psikoanalisis berpendapat bahwa manusia merupakan makhluk homo volens yang memiliki keinginan-keinginan dan memiliki perilaku interaksi antara komponen biologis $(i d)$, psikologis (ego), dan social (superego). Id merupakan pembawaan sifat fisik biologis sejak lahir dan menjadi sumber energi yang memberikan kekuatan terhadap ego dan superego.

Ego adalah lingkup rasional yang berupaya menjinakkan keinginan dari $i d$, dimana ego berupaya mengatur hubungan antara keinginan subjektif individual dan tuntunan objektif realitas sosial. Sedangkan superego berfungsi sebagai aspek moral dalam kepribadian dan selalu mengingatkan ego agar senantiasa menjalankan fungsinya sebagai pengontrol $i d .{ }^{5}$ Sedangkan manusia dalam pandangan teori kognitif berpendapat bahwa manusia adalah homo sapiens yaitu manusia sebagai makhluk yang bereaksi secara aktif dengan lingkungannya karena manusia merupakan makhluk yang berfikir. ${ }^{6}$

Dari berbagai pendapat di atas, pandangan manusia disempurnakan oleh pendapat Al-Qur'an yang menjelaskan bahwa manusia merupakan makhluk homo theopani ${ }^{7}$ atau makhluk berketuhanan yang diberikan kemuliaan dan kesempurnaan, hal ini disebabkan manusia diberikan potensi akal pikiran, dengan akal pikiran tersebut manusia dapat berfikir dan membedakan mana yang baik dan mana yang buruk. Selain dibekali akal pikiran manusia diberikan potensi nafsu, dengan potensi nafsu jika tidak dimanfaatkan dengan baik maka akan menciptakan kejelekan.

Manusia merupakan makhluk Allah yang diciptakan sempurna dibandingkan dengan makhluk lain yang ada di bumi ini, kesempurnaan dan keistimewaan manusia tersebut merupakan karunia yang telah Allah berikan melalui potensi jasmaniah (tubuh), ruhaniah (spiritual), nafsiyah (jiwa) dan aqliyah (pikiran) ${ }^{8}$, potensi tersebut yang dapat menghantarkan manusia sebagai makhluk berakal dan berfikir.

Selain potensi tersebut, menurut al-Maraghi manusia diberikan empat macam hidayah yaitu, hidayah al-ilham (instink), hidayah al-aql (intelegensi), hidayah al-hawâs(indra), hidayah al-adyân wa al syarâi (hukum-hukum agama). ${ }^{9}$

Dengan dibekali akal fikiran, manusia dapat berilmu pengetahuan yang dapat menciptakan sesuatu yang baru dan bermanfaat dan dengan dibekali akal

5 Umar, Nasaruddin. Argumen Kesetaraan Gender Perspektif Al-Qur'an (Jakarta: Paramadina, 2001), 46.

${ }^{6}$ Darwis Hude, Logika Al-Qur'an (Jakarta: Eurobia, 2013), 4.

${ }^{7}$ Informasi manusiamenurut Al-Qur'an dijelaskan sebagai makhluk homo theopani, hal ini dikarenakan manusia diberikan amanah oleh Allah SWT sebagai khalifah fi al-ardh, yang mempunyai tugas dan tanggung jawab menjalankan kehidupan di dunia dengan sebaikbaiknya. Darwis Hude, Logika Al-Qur'an, 4.

${ }^{8}$ Umiarso, Zamroni, Pendidikan Pembebasan Dalam Perspektif Barat dan Timur, (Jakarta: Ar-Ruz Media), 7.

${ }^{9}$ Disarikan oleh Darwis Hude, Logika Al-Qur'an, 5. 
fikiran manusia mampu berkomunikasi antara yang satu dengan yang lain dan dengan perkembangan dan kemajuan komunikasi dan pengetahuan manusia modern dapat menciptakan teknologi, sehingga perkembangan ilmu pengetahuan dan teknologi tersebut dapat dimanfaatkan dan dipergunakan untuk kehidupan manusia dan makhluk lainnya di bumi.

Al-Qur'an sangat menjunjung tinggi nilai-nilai yang terkandung dalam pribadi setiap manusia. Isyarat yang memberikan manusia mendapatkan peluang makhluk yang sempurna tertuang dalam ayat-ayat al-Qur'an dengan menggunakan istilah an-nâs, insan, basyar. ${ }^{10}$

An- Nâs menurut al-Qur'an bermakna eksistensi manusia sebagai makhluk sosial dan sebagai makhluk hidup keturunan Nabi Adam. Dalam alQur'an kata an- nâs disebutkan sebanyak 240 kali dalam 53 surat. ${ }^{11}$ Manusia sebagai an- nâs digunakan al- Qur'an untuk menjelaskan bahwa manusia merupakan makhluk sosial yang tidak dapat hidup tanpa bantuan manusia lain, untuk itu manusia mengembangkan berbagai aktifitas untuk meningkatkan kualitas kehidupannya. Isyarat mengenai makna manusia sebagai an-nâs tertera dalam al-Qur' an surat al- Hujurat/49: 13 sebagai berikut,

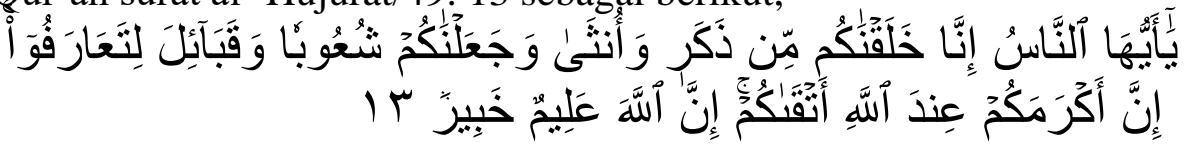

Hai manusia, sesungguhnya Kami menciptakan kamu dari seorang laki-laki dan seorang perempuan dan menjadikan kamu berbangsa-bangsa dan bersukusuku supaya kamu saling kenal-mengenal. Sesungguhnya orang yang paling mulia diantara kamu disisi Allah ialah orang yang paling takwa diantara kamu. Sesungguhnya Allah Maha Mengetahui lagi Maha Mengenal.

Al- Insan secara etimologi al- Insan bermakna harmonis, lemah lembut dan pelupa. Dalam al- Qur'an kata al- Insan disebutkan sebanyak 73 kali dan tersebar dalam 43 surat. ${ }^{12}$ Manusia jika dilihat dari struktur lahir dan bathin memiliki panca indra, otak dan hati yang sempurna. Potensi yang ada dalam diri manusia tersebut merupakan karunia dari Allah SWT yang diberikan hanya kepada manusia, untuk itu jika potensi tersebut dikembangkan dan digunakan ke arah yang baik maka akan menjadi baik, namun jika potensi tersebut dipergunakan ke arah yang tidak baik maka akan menghasilkan keburukan. Isyarat mengenai al-Insan tersebut dijelaskan dalam al- Qur'an surat at-Tiin/95: 4-5 sebagai berikut:

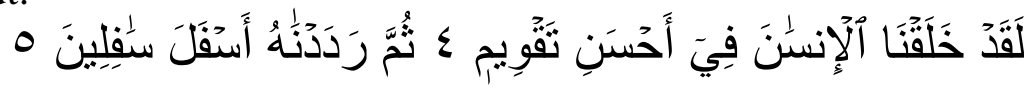

${ }^{10}$ Hamka Abdullah Aziz, Pendidikan Karakter Berpusat pada Hati (Jakarta: AlMawardi, 2012), 26-30.

${ }^{11}$ Quraish Shihab, Wawasa Al-Qur'an Tafsir Maudu'I atas Berbagai Persoalan Umat (Bandung: Mizan, 1998), 281.

${ }^{12}$ Muhamad Fu'ad 'bdul Baqi, al-Mu'jam al-Mufahras li Alfazh al-Qur'an al-Karim (Qahirah: Dar Hadits), 153-154, 159. 
Sesungguhnya Kami telah menciptakan manusia dalam bentuk yang sebaikbaiknya. Kemudian Kami kembalikan dia ke tempat yang serendah-rendahnya (neraka).

Jalaluddin Rahmat menjelaskan kata al-Insan dengan tiga kategori, pertama, manusia sebagai khalifah dan pemikul amanah, kedua manusia predisposisi negatif pada diri manusia, ketiga manusia berhubungan dengan potensi manusia. $^{13}$

Jika dilihat dari penjelasan di atas, kata al-Insan dapat dijelaskan mengenai proses kejadian manusia secara dinamis dan sempurna, yaitu manusia yang mempunyai tanggung jawab untuk menjadi pemimpin, baik pemimpin untuk diri sendiri, keluarga dan masyarakat, serta fungsi manusia sebagai pelengkap manusia lain, sehingga antara manusia yang satu dengan yang lain dapat bekerja sama untuk saling melengkapi dan memperbaiki diri, potensi manusia juga memiliki potensi negatif dan kejelekan dalam bentuk nafsu, yang senantiasa harus dikendalikan agar potensi tersebut dapat diminimalisir.

$A l$ - Basyar secara etimologi mengandung arti sesuatu yang indah, gembira dan baik. Dalam Al-Qur'an kata al-Basyar dijelaskan sebanyak 27 kali. ${ }^{14}$ Menurut Quraish Shihab, kata basyar mengandung arti menampakkan sesuatu dengan baik dan indah. Dari kata yang serupa lahirlah kata basyarah yang berarti kulit. Manusia disebut basyarah karena kulit manusia tampak jelas dan indah berbeda dengan kulit binatang. ${ }^{15}$

Al- Basyar mengandung pengertian bahwa manusia mengalami proses reproduksi seksual dan senantiasa berupaya untuk memenuhi semua kebutuhan biologis, memiliki ruang dan waktu serta tunduk kepada hukum alamiah, baik yang berupa ketentuan Allah (takdir) maupun yang bersifat kemanusiaan (sunatullah). Isyarat manusia sebagai makhluk biologis, Allah jelaskan dalam Al-Qur'an surat Yusuf/12: 3̧1 sebagai berikut,

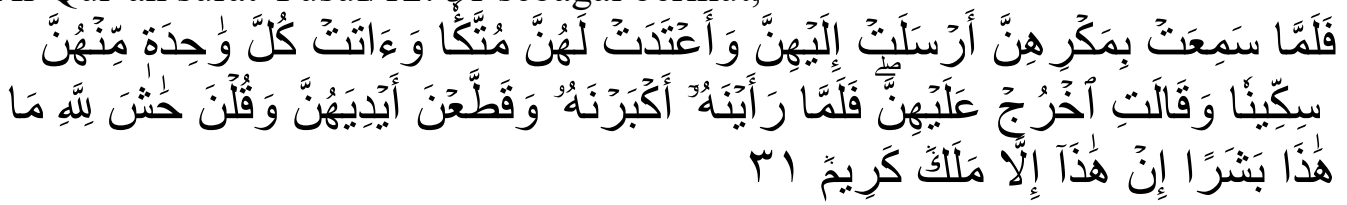

Maka tatkala wanita itu (Zulaikha) mendengar cercaan mereka, diundangnyalah wanita-wanita itu dan disediakannya bagi mereka tempat duduk, dan diberikannya kepada masing-masing mereka sebuah pisau (untuk memotong jamuan), kemudian dia berkata (kepada Yusuf): "Keluarlah (nampakkanlah dirimu) kepada mereka". Maka tatkala wanita-wanita itu melihatnya, mereka kagum kepada (keelokan rupa) nya, dan mereka melukai

${ }^{13}$ Dawam Rahardjo, Ensiklopedia Islam: Tafsir Sosial Berdasarkan Konsep-Konsep Kunci (Jakarta: Paramadina, 2002), 55.

${ }^{14}$ Muhamad Fu'ad 'bdul Baqi, al-Mu'jam al-Mufahras li al-fazh al-Qur'an al-Karim, 153-154.

${ }^{15}$ Quraish Shihab, Wawasan al-Qur'an, 279. 
(jari) tangannya dan berkata: "Maha sempurna Allah, ini bukanlah manusia. Sesungguhnya ini tidak lain hanyalah malaikat yang mulia".

Ayat ini menceritakan mengenai perempuan-perempuan pembesar Mesir yang didukung Zulaikha takjub melihat ketampanan Nabi Yusuf, dalam konteks ayat ini yang dilihat adalah aspek biologis. Untuk itu sebagai al-Basyar, Allah memberikan kekuatan dan kebebasan dengan batasan potensi yang dimiliki untuk mengelola alam semesta.

Pendapat lain kata al-Basyar merupakan pemahaman tentang manusia ditinjau dari sisi kecerdasan, memahami keberadaan diri (eksistensi), alam semesta dan Allah SWT. ${ }^{16}$ Isyarat ini dijelaskan dalam al-Qur'an surat Fushshilat/41: 6 sebagai berikut,

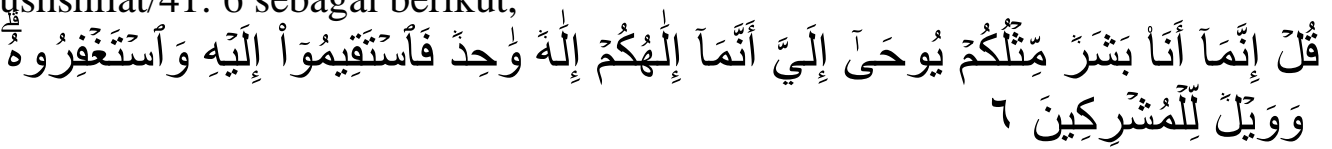

Katakanlah: "Bahwasanya aku hanyalah seorang manusia seperti kamu, diwahyukan kepadaku bahwasanya Tuhan kamu adalah Tuhan yang Maha Esa, maka tetaplah pada jalan yang lurus menuju kepada-Nya dan mohonlah ampun kepada-Nya. Dan kecelakaan besarlah bagi orang-orang yang mempersekutukan-Nya.

Jika dilihat dari ayat di atas, setiap manusia memiliki kemampuan dan kecerdasan untuk melakukan transformasi nilai yang bersifat dialogis, yang dapat saling mengisi antara satu dengan lainnya.

Bani Adam merupakan sebutan dalam Al-Qur'an terhadap manusia. Bani adam dalam Al-Qur'an mempunyai pengertian bahwa manusia beserta keturunannya mengandung pengertian basyar, insan dan an-nas. Istilah ini disebutkan dalam Al-Qur'an sebanyak 9 kali. ${ }^{17}$ Berikut ayat Al-Qur'an yang mengandung makna bani adam adalah Al-Qur'an surat yasin/36: 50sebagai berikut:

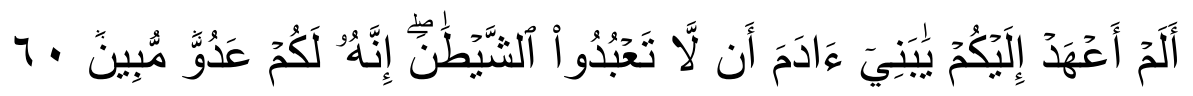

Bukankah Aku telah memerintahkan kepadamu hai Bani Adam supaya kamu tidak menyembah syaitan? Sesungguhnya syaitan itu adalah musuh yang nyata bagi kamu".

Kata Bani Adam ditekankan pada aspek amaliah manusia, dan juga pemberi arah aktifitas manusia yang dilakukan. ${ }^{18}$ Istilah bani adam ini merupakan kekhususan yang diberikan kepada manusia mengenai potensi akal dan potensi jasmani (fisik) serta kemampuan ilmu pengetahuan yang tidak dimiliki oleh makhluk lain selain manusia.

16 Hamka Abdul Aziz, Pendidikan Karakter Berpusat pada Hati (Jakarta: AlMawardi, 2012), 28.

${ }^{17}$ Moh. Hasyim dan Zaki Mubarok, Akidah Islam (Yogyakarta: UII Press, 1998), 1-3.

${ }^{18}$ Samsul Nizar, Filsafat Pendidikan Islam, Pendekatan Historis, Teoritis dan Praktis (Jakarta: Ciputat Press, 2002), 14. 


\section{Konsep Relasi Sosial dalam Al-Qur'an}

Dalam kamus Sosiologi istilah relasi sosial (relationship social) diartikan sebagai perangkat pola hubungan pribadi yang sama (hubungan sosial). ${ }^{19}$ Sedangkan menurut Michener \& Delamater mendefinisikan relasi sosial juga disebut hubungan sosial yang merupakan hasil dari interaksi (rangkaian tingkah laku) yang sistematik antara dua orang atau lebih. Hubungan dalam relasi sosial merupakan hubungan yang sifatnya timbal balik antar individu yang satu dengan individu yang lain dan saling mempengaruhi. ${ }^{20}$

Relasi sosial merupakan rangkaian dari interaksi sosial antara manusia satu dengan yang lainnya yang lambat laun saling bekerjasama dan mempengaruhi. Dalam relasi sosial, dengan kemampuan manusia yang mempunyai kelebihan dan kekurangan juga memiliki kecocokan antara yang satu dengan yang lainnya akan menghasilkan pola relasi sosial assosiatif yaitu pola hubungan kerjasama, asimilasi, akulturasi dan pola diassosiatif yaitu pola oposisi dalam bentuk persaingan.

Terbentuknya pola assosiatif dan diassosiatif dalam relasi sosial adalah hal yang wajar, mengingat manusia mempunyai kecenderungan berbuat baik dan berbuat buruk. Untuk itu, Al-Qur'an memberikan pesan untuk membangun pola relasi sosial ini dengan isyarat yang disampaikan dalam Al-Qur'an Surat al-Hujuratt49: 13:

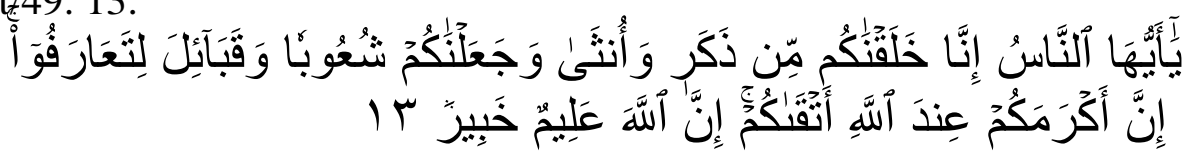

Hai manusia, sesungguhnya Kami menciptakan kamu dari seorang laki-laki dan seorang perempuan dan menjadikan kamu berbangsa-bangsa dan bersukusuku supaya kamu saling kenal-mengenal. Sesungguhnya orang yang paling mulia diantara kamu disisi Allah ialah orang yang paling takwa diantara kamu. Sesungguhnya Allah Maha Mengetahui lagi Maha Mengenal.

Ayat ini diturunkan berkenaan dengan perintah Rasulullah SAW memerintahkan Bani Bayadhah untuk menikahkan Abu Hindun dengan seorang perempuan dari kalangan mereka yaitu hamba sahaya. Pendapat lain menjelaskan bahwa ayat ini turun tentang Tsabit bi Qais bin Syamas dan ucapannya yang tidak memberikan tempat pada dirinya, Tsabit melihat ada

${ }^{19}$ Soerjono Soekanto, Kamus Sosiologi (Jakarta: CV Rajawali, 1985), 427.

${ }^{20}$ Beberapa tahapan terjadinya relasi sosial yaitu (a) Zero contact yaitu kondisi dimana tidak terjadi hubungan antara dua orang; (b) awarness yaitu seseorang sudah mulai menyadari kehadiran orang lain; (c) surface contact yaitu orang pertama menyadari adanya aktivitas yang sama oleh seseorang di sekitarnya; dan (d) mutuality yaitu sudah mulai terjalin relasi sosial antara 2 orang yang tadinya saling asing". D. S. Hidayati, Peningkatan Relasi Sosial melalui Social Skill Therapy pada Penderita Schizophrenia Katatonik". Jurnal Online Psikologi, 2 (1): 17-28. 
yang merah, hitam dan putih, Rasulullah bersabda sesungguhnya engkau tidak dapat mengungguli mereka kecuali ketakwaannya. ${ }^{21}$

Dari tafsir ayat tersebut dijelaskan manusia merupakan ciptaan Allah SWT yang diciptakan bersuku-suku, berbangsa-bangsa tujuannya untuk saling mengenal antar manusia yang satu dengan yang lainnya, sehingga dengan mengenal tersebut manusia saling berinteraksi dan saling melengkapi juga saling membutuhkan, serta bekerjasama dalam berbagai kebutuhan hidup, dan dalam tafsir ayat ini dijelaskan bahwa tidak diperkenankan untuk menghina dan tidak menghargai sesama manusia, karena yang menjadi penilaian di hadapan Allah SWT bukan fisik dan kecerdasan, namun ketakwaannya.

Sedangkan menurut Quraish Shihab dalam Tafsir Misbah menjelaskan bahwa kata ta'ârafû berasal dari kata 'arafa yang berarti mengenal. Semakin kuat pengenalan satu dengan yang lainnya maka akan bayak memberikan manfaat. Perkenalan bertujuan untuk saling mengambil pelajaran, bekerjasama, tolong menolong dan saling menghargai tanpa itu semua relasi sosial tidak akan terwujud. $^{22}$

Al-Qur'an Surat al-Hujurat/49: 9 tersebut memberikan pesan dalam melakukan hubungan sosial secara keseluruhan, tidak hanya berbicara dalam satu agama akan tetapi berbicara lintas suku, kabilah, bangsa yang bertujuan untuk saling mengenal. Sehingga ketika sudah terjadi saling mengenal akan menimbulkan kedekatan untuk melakukan hubungan sosial yang lebih bermanfaat.

\section{Prinsip Dasar Relasi Sosial dalam Al-Qur'an}

Untuk lebih menekankan pentingnya melakukan relasi sosial, maka perlu berikan prinsip dasar yang dapat menjadi landasan setiap manusia ketika melakukan relasi sosialTafsir surat al-Hujurat/49:13:

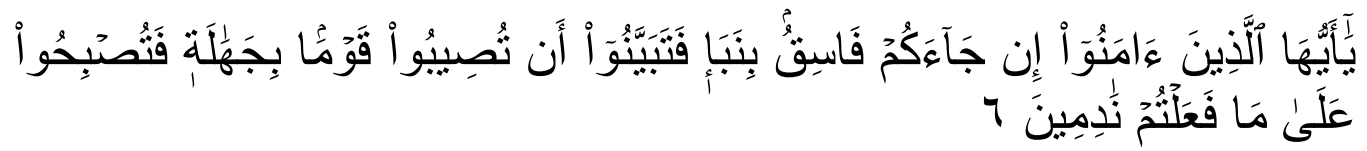

Hai orang-orang yang beriman, jika datang kepadamu orang fasik membawa suatu berita, maka periksalah dengan teliti agar kamu tidak menimpakan suatu kamu menyesal atas perbuatanmu itu.

${ }^{21}$ Syaikh Imam Qurthubi, Tafsir Al-Qurtubi Akhmad Khatib (penerjemah), judul asli Al-Jami' li Ahkaam Al-Qur'an (Jakarta: Pustaka Azzam, 2009), 101-102.

${ }^{22}$ Quraish Shihab, Tafsir al-Misbah (Jakarta: Lentera Hati, 2007), 364. 
Asbab an-nuzul ayat di atas berkaitan dengan kabar berita bohong yang disampaiakn oleh al-Walid bin Uqbah ketika Rasulullah ke Bani Mustaliq. Walid memberikan laporan kepada Rasulullah bahwa penduduk Bani Mustaliq enggan untuk membayar zakat dan berniat membunuh Walid padahal Walid yang diutus oleh Rasulullah tidak datang ke Bani Mustaliq dan memberikan berita bohong. Rasulullah memerintahkan Walid untuk mengklarifikasi (tabayyun) kebenarannya. Maka turunlah ayat tersebut. ${ }^{23}$

Kata fatabayyan̂ิ mengandung arti meminta penjelasan dan klarifikasi. ${ }^{24}$ Ayat ini merupakan ayat peringatan untuk setiap manusia yang menerima berita baik secara lisan maupun tertulis. Ayat di atas menjelaskan tentang pentingnya klarifikasi atau meminta penjelasan kembali terhadap berita yang diterima baik secara lisan maupun tertulis. Hal ini berkaitan erat dengan fenomena saat ini, dimana informasi yang beredar di media sosial terutama hendaklah diwaspadai dan klarifikasi kebenarannya karena mengandung hoax. Ketika berita yang disampaikan tidak sesuai dan berbohong (hoax) maka Allah memberikan label sebagai orang fasik.

Selain diberikan kategori fasik, para penebar berita bohong merupakan manusia tidak bertanggung jawab karena telah meresahkan masyarakat dan melakukan perbuatan fitnah, yaitu memberikan informasi tidak sesuai data yang ada. Selain meresahkan masyarakat perilaku tersebut berpotensi mengancam keamanan suatu wilayah.

Isyarat perlunya menjaga komunikasi, relasi sosail dan informasi yang baik antar sesama manusia Allah SWT sampaikan dalam Al-Qur'an Surat alHujurat/49: 11-12:

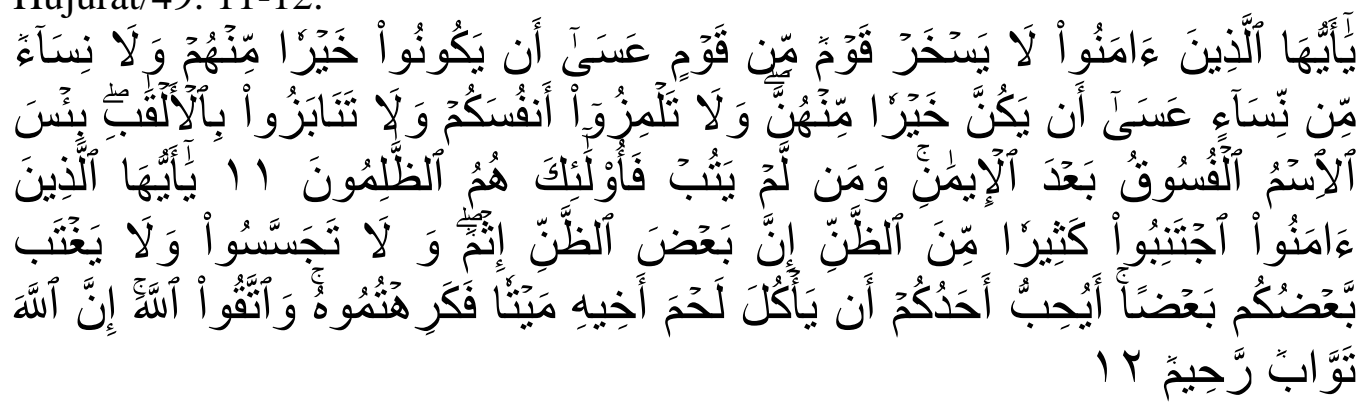

Hai orang-orang yang beriman, janganlah sekumpulan orang laki-laki merendahkan kumpulan yang lain, boleh jadi yang ditertawakan itu lebih baik dari mereka. Dan jangan pula sekumpulan perempuan merendahkan kumpulan

${ }^{23}$ Dalam Tafsir Ibnu Katsir disarikan oleh Badan Litbang dan Diklat Kementerian Agama RI, Tafsir Al-Qur'an Tematik: Komunikasi dan Informasi (Jakarta: Lajnah Pentashih Mushaf Al-Qur'an, 2001), 415.

${ }^{24}$ Kata nabaa secara Bahasa bermakna khabar, sedangkan kata annabaa mengandung pengertian sesuatu kabar yang penting dan memiliki faidah yang besar. Muhammad 'Ali asSabuni, Rawâ'I'ul-Bayân Tafsir Ayat al-ahkâm minal-Qur'an, Juz 2 (Jakarta: Darul-Kutub alIslamiyyah, 2001), 383. 
lainnya, boleh jadi yang direndahkan itu lebih baik. Dan janganlah suka mencela dirimu sendiri dan jangan memanggil dengan gelaran yang mengandung ejekan. Seburuk-buruk panggilan adalah (panggilan) yang buruk sesudah iman dan barangsiapa yang tidak bertobat, maka mereka itulah orangorang yang zalim.

Hai orang-orang yang beriman, jauhilah kebanyakan purba-sangka (kecurigaan), karena sebagian dari purba-sangka itu dosa. Dan janganlah mencari-cari keburukan orang dan janganlah menggunjingkan satu sama lain. Adakah seorang diantara kamu yang suka memakan daging saudaranya yang sudah mati? Maka tentulah kamu merasa jijik kepadanya. Dan bertakwalah kepada Allah. Sesungguhnya Allah Maha Penerima Taubat lagi Maha Penyayang.

Prinsip relasi sosial selanjutnya dijelaskan dalam Surat al-Hujurat/49:1112 sebagai berikut, Pertama, larangan mengolok-olok orang lain dengan cara menghina dan mencela serta meremehkan orang lain. Ibnu Katsir menghukumi haram atas perbuatan tersebut, karena perbuatan tersebut dapat menyaiti hati dan menimbulkan kebencian. Selain itu orang yang dihina dan dicela belum tentu hina di mata Allah SWT. Kedua mencela dirimu sendiri maksud kalimat tersebut menurut Ibnu 'Abbas, Mujahid, Sa'id bim Jubair, Qatadah dan Muqatil bin Hayyan menjelaskan bahwa janganlah sebagain menikam sebagain yang lain. Ketiga memberikan panggilan yang buruk. Imam Ahmad menjelaskan berdasarkan hadits dari Rasulullah yang berkenaan dengan Bani Salamah menjelaskan bahwa Rasulullah sampai di Madinah dan di antara kami tidak seorangpun melainkan mempunyai dua atau tiga nama. Dan jika Rasulullah memanggil salah seorang dari mereka dengan nama tersebut, mereka berkata: "Ya Rasulullah sesungguhnya ia marah dengan panggilan nama tersebut". Keempat larangan melakukan tuduhan dan penghianatan baik terhadap keluarga, maupun umat manusia dengan cara berprasangka, karena sebagain prasangka itu murni menjadi perbuatan dosa. Dan menjauhi prasangka merupakan suatu kewaspadaan. Kelima larangan mencari-cari kesalahan orang lain. Kata tajassasu bermakna mata-mata. Mencari keburukan dapat dilakukan dengan mengintai kesalahan orang lain yang dapat menimbulkan kebencian dan dengan mencari keburukan orang lain berarti telah merusak kehidupan. Keenam, Larangan untuk menggunjing sebagain dengan sebagian yang lain. Dalam kalimat tersebut juga terdapat larangan ghibah. Ghibah menurut sabda Rasulullah SAW adalah menceritakan perihal saudaramu yang tidak disukai. 
Jika keadaannya sesuai maka hal tersebut adalah ghibah, namun jika tidak sesuai fakta maka termasuk berbohong atau berdusta. ${ }^{25}$

\section{Etika Relasi Sosial dalam Al-Qur'an}

Al-Qur'an memberikan tuntunan etika dalam melakukan hubungan sosial di masyarakat, isyarat tersebut tertuang dalam surat an-Nahl/16: 125 sebagai berikut:

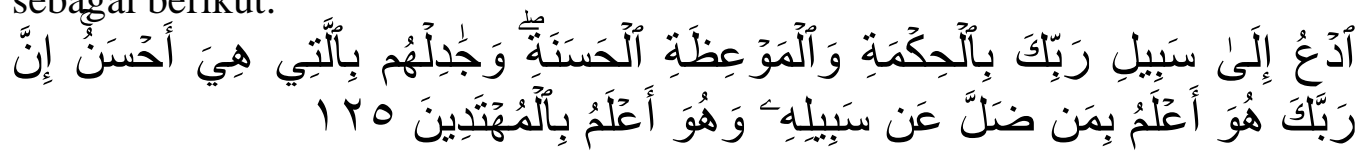

Serulah (manusia) kepada jalan Tuhan-mu dengan hikmah dan pelajaran yang baik dan bantahlah mereka dengan cara yang baik. Sesungguhnya Tuhanmu Dialah yang lebih mengetahui tentang siapa yang tersesat dari jalan-Nya dan Dialah yang lebih mengetahui orang-orang yang mendapat petunjuk.

Menurut al-Qurtubi ayat ini menjelaskan tentang Rasulullah yang diperintahkan untuk menghadapi kekejaman Quraisy. Allah memerintahkan Rasulullah berdakwah untuk menyeru kepada agama Allah dan menjalankan syariat Allah SWT kepada kaum Quraisy dengan cara hikmah, mau'izhah hasanah dan mujadalah. ${ }^{26}$

Metode komunikasi yang dilakukan dengan hikmah, mau'izhah hasanah dan mujadalah merupakan pilihan metode yang dapat disampaikan dengan disesuaikan kondisi dan situasi siapa yang akan menerima dakwah Rasulullah. Hal ini dimaklumi karena setiap individu memiliki karakter, sifat dan kebutuhan yang berbeda dalam hal keilmuan dan pemahaman keagamaan. Dengan harapan pesan yang disampaikan dapat diterima dan sesuai dengan kebutuhan masingmasing. Seperti contoh, seseorang yang senang dalam kebaikan akan tetapi enggan atau lalai dalam melaksanakan kebaikan, maka metode yang bisa disampaikan adalah dengan cara hikmah. Hikmah menurut Quraish Shihab ${ }^{27}$ adalah segala sesuatu jika digunakan atau diperhatikan akan mendatangkan kemaslahatan dan kemudahan yang besar atau lebih besar, serta menghalangi terjadinya madharat atau kesulitan yang besar atau lebih besar. Atau dalam suatu masyarakat ada yang menentang dan tidak suka kepada kebenaran, maka metode mau'izhah hasanah yaitu dengan cara menjelaskan anjuran (targhib) dan ancaman (tarhib) dapat dijadikan cara untuk menjelaskan bahwa seseorang yang memegang kebenaran akan mendapatkan pahala dan kebaikan dan

25 Abdullah bin Muhammad bin 'Abdurrahman bin Ishaq Alu Syaikh, Tafsir Ibnu Katsir, 485-491.

${ }^{26}$ Abu Abdullah Muhammad bin Ahmad al-Anshari al-Qurthubi, al-Jami'il Ahkam AlQur'an, cet ke-1 (Beirut: Daar-al-Fikr, 1999), 146.

${ }^{27}$ Quraish M. Shihab, Tafsir al-Misbah: Pesan, Kesan, dan Keserasian Al-Qur'an (Jakarta: Lentera Hati, 2002), 386. 
seseorang yang memegang teguh kejelekan akan merugi. Jika dalam pengajaran menemukan golongan atau kelompok yang memiliki kerancuan pemikiran yang menghalangi dalam kebenaran, maka metode pendidikan yang tepat adalah dengan mujadalah (berdebat) dengan cara yang baik.

Selain itu etika hubungan sosial juga diatur untuk para penganut agama terutama hubungan sosial antara umat Islam dan umat lainnya, Isyarat tersebut terdapat dalam Al-Qur'an Surat al-Mumtahanah/60: 8-9:

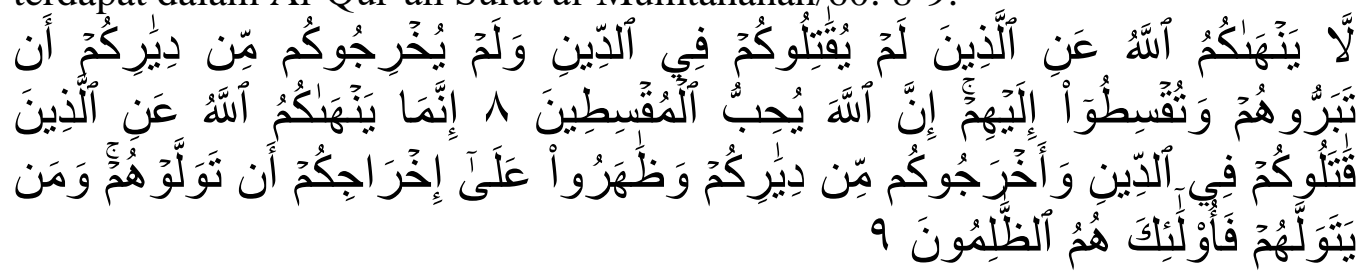

Allah tidak melarang kamu untuk berbuat baik dan berlaku adil terhadap orang-orang yang tiada memerangimu karena agama dan tidak (pula) mengusir kamu dari negerimu. Sesungguhnya Allah menyukai orang-orang yang berlaku adil

Sesungguhnya Allah hanya melarang kamu menjadikan sebagai kawanmu orang-orang yang memerangimu karena agama dan mengusir kamu dari negerimu, dan membantu (orang lain) untuk mengusirmu. Dan barangsiapa menjadikan mereka sebagai kawan, maka mereka itulah orang-orang yang zalim

Al-Maraghi menjelaskan bahwa Allah tidak melarang berlaku adil dan berbuat baik kepada non muslim yang tidak menyerang, memusuhi dan mengusir orang-orang Islam dari negeri yang orang Islam tempati. Akan tetapi Allah melarang untuk berbuat baik dan berlaku adil terhadap orang-orang yang memusuhi, menganiaya dan mengusir dari tempat tinggal sehingga menimbulkan permusuhan dan penganiayaan, sebagaimana yang dilakukan oleh orang-orang musyrik Mekah terhadap orang-orang muslim pada masa Rasulullah SAW. ${ }^{28}$ Dalam ayat tersebut Allah menyuruh berbuat baik dan berlaku adil terhadap orang-orang muslim dan non muslim yang dapat hidup bersama, berdampingan, tentram dan damai dan tidak menimbulkan permusuhan.

\section{Penutup \\ Kesimpulan}

Allah SWT menciptakan manusia di bumi ini dengan berbagai suku, adat, bangsa, negara. Hal ini bertujuan untuk saling mengenal dan tercipta relasi sosial. Dalam Al-Qur'an terdapat isyarat-isyarat mengenai relasi sosial yang

${ }^{28}$ Ahmad Musthafa al-Maraghi, Tafsir al-Maraghi ... hal. 70 
berkaitan dengan relasi sosial antar bangsa, bernegara maupun relasi yang berhubungan antar agama. Kandungan ayat-ayat dalam Al-Qur'an tersebut menjelaskan etika relasi sosial secara rinci yang dapat menjadi landasan dan panduan umat Islam dalam melaksanakan hubungan baik, dengan isyarat yang terdapat dalam Al-Quran dan dijadikan landasan dalam kehidupan akan menciptakan relasi sosial yang menentramkan.

\section{DAFTAR PUSTAKA}

Al-Imam Abu al-Qasim Jarullah Mahmud bin 'Umar al-Zamakhsyari, tth. "alKasysyaf 'an Haqaiq al-Tanzil wa al-'Uyun al-Aqawil fi wujuh alTa'wil”, Beirut : Dar al-Kitab al-'Arabi, tth.

Aziz, Hamka Abdul. 2012. "Pendidikan Karakter Berpusat pada Hati”, Jakarta: Al-Mawardi.

Baqi, Muhamad Fu'ad 'bdul. "al- Mu'jam al-Mufahras li Alfazh al-Qur'an alKarim", Qahirah: Dar Hadits.

Badan Litbang dan Diklat Kementerian Agama RI. 2001. "Tafsir Al-Qur'an Tematik: Komunikasi dan Informasi”, Jakarta: Lajnah Pentashih Mushaf Al-Qur'an.

Hakim, Usman A. 2001. "Kamus Bahasa Indonesia", Jakarta: Balai Pustaka. Hidayati, D. S. 2013. "Peningkatan Relasi Sosial melalui Social Skill Therapy pada Penderita Schizophrenia Katatonik". Jurnal Online Psikologi, 2 (1).

Hude, Darwis. 2015. 'Logika Al-Qur'an", Jakarta: Eurobia.

Madjid, Abdul Latief. 2014. "Evaluasi Kinerja SDM: Konsep Aplikasi, Standard dan Penelitian", Jakarta: Haja Mandiri. 
Mubarok, Moh. Hasyim dan Zaki. 1998. "Akidah Islam", Yogyakarta: UII Press.

Nawawi, Hadari Mimi Martini 1994. "Manusia Berkualitas", Yogyakarta: Gajah Mada University Press.

Nizar, Samsul. 2002. "Filsafat Pendidikan Islam, Pendekatan Historis, Teoritis dan Praktis", Jakarta: Ciputat Press.

Nuh, Abdullah bin. 2008. "Kamus Indonesia Arab", Jakarta: Mutiara.

Rahardjo, Dawam. 2002. "Ensiklopedia Islam: Tafsir Sosial Berdasarkan Konsep-Konsep Kunci", Jakarta: Paramadina.

as-Sabuni, Muhammad 'Ali. 2001. "Rawâ'i'ul-Bayân Tafsir Ayat al-ahkâm minal-Qur'an”, Juz 2, Jakarta: Darul-Kutub al-Islamiyyah.

Shihab, Quraish. 1998. "Wawasan Al-Qur'an Tafsir Maudu'I atas Berbagai Persoalan Umat", Bandung: Mizan.

Shihab, Quraish. 2007. "Tafsir al-Misbah", Jakarta: Lentera Hati.

Suharto, Dedhi. "Qur'anic Intelligence Quotient (membangun kecerdasan AlQur'an) ", Tangerang: FBA Press.

Soekanto, Soerjono. 1985. "Kamus Sosiologi”, Jakarta: CV Rajawali.

Umar, Nasaruddin. 2001. "Argumen Kesetaraan Gender Perspektif Al-Qur'an, Jakarta: Paramadina.

Umiarso, Zamroni. 2011. "Pendidikan Pembebasan Dalam Perspektif Barat dan Timur", Jakarta : Ar-Ruz Media.

Qurthubi, Syaikh Imam. 2009. "Tafsir Al-Qurtubi Akhmad Khatib”, Jakarta: Pustaka Azzam. 